\title{
A Template for Family-Centered Interagency Collaboration
}

\author{
by Uta M. Walter \& Christopher G. Petr
}

\section{Abstract}

In this paper, it is asserted that successful interagency collaborations require commitment to a shared value base as the core dimension of the joint efforts. A rationale framework that places family-centered principles at the core is provided, and how these principles translate into specific behaviors, attitudes, and policies on all levels within and between organizations is outlined. This template can provide guidance to local and state policy makers involved in reforming systems of care.

THE TERMS “family-centered services" and "interagency collaboration" are commonly used to describe preferred reforms to the multiple systems of care that envelop needy children and families. Yet, the two terms are rarely linked together, and their interrelationship has not been fully explored in the literature. Family-centered services have generally been discussed in relationship to behaviors of professionals or to agency and program characteristics within agencies, with scant attention paid to the application of familycentered principles between agencies with respect to interagency councils and other collaboratives at community and state levels. The aim of this article is to provide a rationale and specific framework, or template, for adopting family-centered principles as the core set of values undergirding interagency collaborative efforts.

\section{Interagency Collaboration Defined}

Interagency collaboration is a key strategy in recent efforts to turn fragmented human services into a system that addresses the multiple needs of children and families in a more comprehensive and efficient way. It is closely linked to initiatives of service integration, and the literature shows a growing consensus about the need for interagency collaboration (O'Looney, 1994). Definitions and concepts of interagency collaboration can be found across disciplines and service systems, and in the literature of social ser- vices, education, early intervention, mental health, and health care (Hassett \& Austin, 1997; Konrad, 1996; O'Looney, 1994; Swan \& Morgan, 1993; Melaville \& Blank, 1991).

While the Latin roots of "collaboration" simply translate into "working together," a multitude of definitions and models of interagency collaboration has evolved in recent years (Kagan, 1991, 1993; Kagan \& Pritchard, 1996; Urwin \& Haynes, 1998; Hassett \& Austin, 1997; O'Looney, 1994; Mattessich \& Monsey, 1992; Bruner, 1991). Interagency collaboration has been characterized in many ways: as a structure as well as a process (Abramson, \& Rosenthal, 1995); as both process and attitude (Swan \& Morgan, 1993); and as a relationship involving formal and informal components with varying emphases on either aspect (Swan \& Morgan, 1993; Konrad, 1996; Harbert, Finnegan, \& Tyler, 1997). While Swan and Morgan (1993) correctly point out that the meaning and functional definitions of collaboration continue to be researched, some common conceptual themes and dimensions have emerged.

Abramson and Rosenthal (1995), in the Encyclopedia of Social Work, define interagency collaboration as "a fluid process through which a group of diverse, autonomous actors (organizations or individuals) undertakes a joint initiative, solves shared problems, or otherwise achieves common goals." Characterized by "mutual benefit, interdependence, reciprocity, concerted action and joint production," interagency col- 


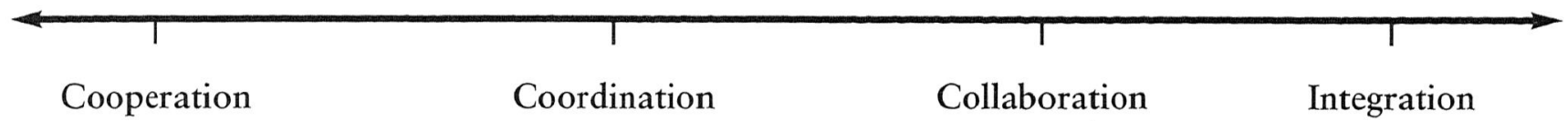

Note. Adapted from Konrad, E. L. (1996). A multidimensional framework for conceptualizing human services integration initiatives. New Directions for Evaluations, 69, 5-19. (C) 1996, John Wiley \& Sons, Inc. Reprinted by permission of Jossey-Bass, Inc., a subsidiary of John Wiley \& Sons, Inc.

laboration entails "ideally, a common vision; a jointly developed structure; the sharing of work, resources and rewards" (p. 1479). Swan and Morgan (1993) claim interagency collaboration is a "radical departure" from traditional agency functions and requires powerful commitments to change.

Because the term interagency collaboration is often used interchangeably with "coordination," "cooperation," or "service integration," it is useful to clearly distinguish these terms by placing them all on a service-integration continuum. Together, cooperation, coordination, and interagency collaboration form a continuum or a hierarchy of increasingly shared decision-making processes and structures (Kagan, 1991; Konrad, 1996; Swan \& Morgan, 1993), culminating in full service integration. Thus, interagency collaboration is one of the processes by which service integration is achieved.

Bruner (1991) distinguishes interagency collaboration from cooperation and coordination. Cooperation is an informal exchange between agencies, with more or less frequent communication and a form of friendly coexistence. Coordination efforts involve some formal relations between agencies, whose staff will meet regularly to share plans, ideas, and joint activities, but each agency maintains its own set of goals, structures, and responsibilities, such that agencies are not truly accountable to each other. Collaboration, in contrast, involves joint activities, joint structures, and shared resources.

Collaboration is described as a partnership formation (O'Looney, 1997) that denotes a durable and pervasive relationship (Harbert et al., 1997) and that is characterized by mutual benefits, interdependence, and a formal commitment of working together for specific purposes and outcomes (Bailey \& Koney, 1996). Definitions differ as to the degree to which in- teragency collaboration requires a change of agency structures and relinquishing of autonomy, but some pooling of resources and merging of organizational structures appear necessary for collaborative efforts to attain the level of service integration.

Collaborations among agencies can take place on the service level, involving supervisory support for frontline personnel, or on the administrative level (Jesien, 1996), requiring altered structures and functions of participating agencies. Case-level interagency efforts would best be characterized as cooperation or coordination, not interagency collaboration, unless they are a part of a larger administrative-level collaboration that entails some degree of shared responsibility, resources, and authority. Thus, in this paper, the term interagency collaboration is used to refer to the two highest levels depicted in Figure 1: collaboration and service integration.

\section{Dimensions of Interagency Collaboration}

In an attempt to further define, describe, and analyze interagency collaboration, nine domains or dimensions have been identified in the conceptual literature about interagency collaboration (Urwin \& Haynes, 1998; Austin, 1997): (a) stakeholder involvement; (b) common goals or tasks; (c) shared responsibilities; (d) shared rewards; (e) shared resources; (f) shared authority or decision making; (g) shared evaluations; (h) shared structures; and (i) shared visions and values.

The last dimension, shared visions and values, has been highlighted as being crucial to successful collaborative efforts. This dimension has been described as the glue that holds collaborative efforts together (Bailey \& Koney, 1996; Harbert, Finnegan, \& Tyler, 1997). Lessons from earlier waves of service-integration 
efforts have shown that conflicts in visions and motivations can account for failures and faded efforts, and that it is necessary to ensure that staff and communities buy into the prospective changes on all levels (Hassett \& Austin, 1997; Morgan, 1997). "Consonance of values" has been identified as one essential precondition for successful collaboration in studies of earlier service-integration efforts (Morgan, 1997). A dissonance in values and motivations for integrating services underlies unsuccessful attempts that failed to include staff and communities, or imposed agendas and unrealistic expectations in a top-down approach (Hassett \& Austin, 1997).

It makes sense that without anchoring goals, objectives, and all other dimensions of the collaborative process in a shared value base, interagency collaboration is futile. Given this centrality of common values for successful interagency collaboration, an explicit and shared value base is not merely one dimension of interagency collaboration, but, rather, it constitutes its very core. All other aspects of interagency collaboration must revolve around this guiding core. Attitudes and activities of direct practitioners, agency management, and interagency activities then emanate from this core (see Figure 2).

\section{Family-Centered Values as Core of Interagency Collaboration}

What should constitute this shared value system? What values and beliefs should be at the core of all agencies' helping efforts? In this section, a rationale for adopting family-centered values as the core value system for interagency collaborations is presented. This rationale is founded on two themes: (a) the paramount importance of supporting the viability and integrity of the family as our most important social institution and (b) the need to be wary of professional values and perspectives dominating the process.

Several authorities suggest that the beliefs and values embodied under the rubric of "familycentered" offer the best hope for improving outcomes for children and families. In 1991, the bipartisan $\mathrm{Na}$ tional Commission on Children concluded, "At a time when the family is imperiled by extraordinary social, demographic, and economic change and instability, every part of American society must ask what it can do to strengthen families" (National Commission on Children, 1991, p. xi). Service agencies are not immune from this imperative. Morgan (1997), in discussing the role of values in interagency collaboration,

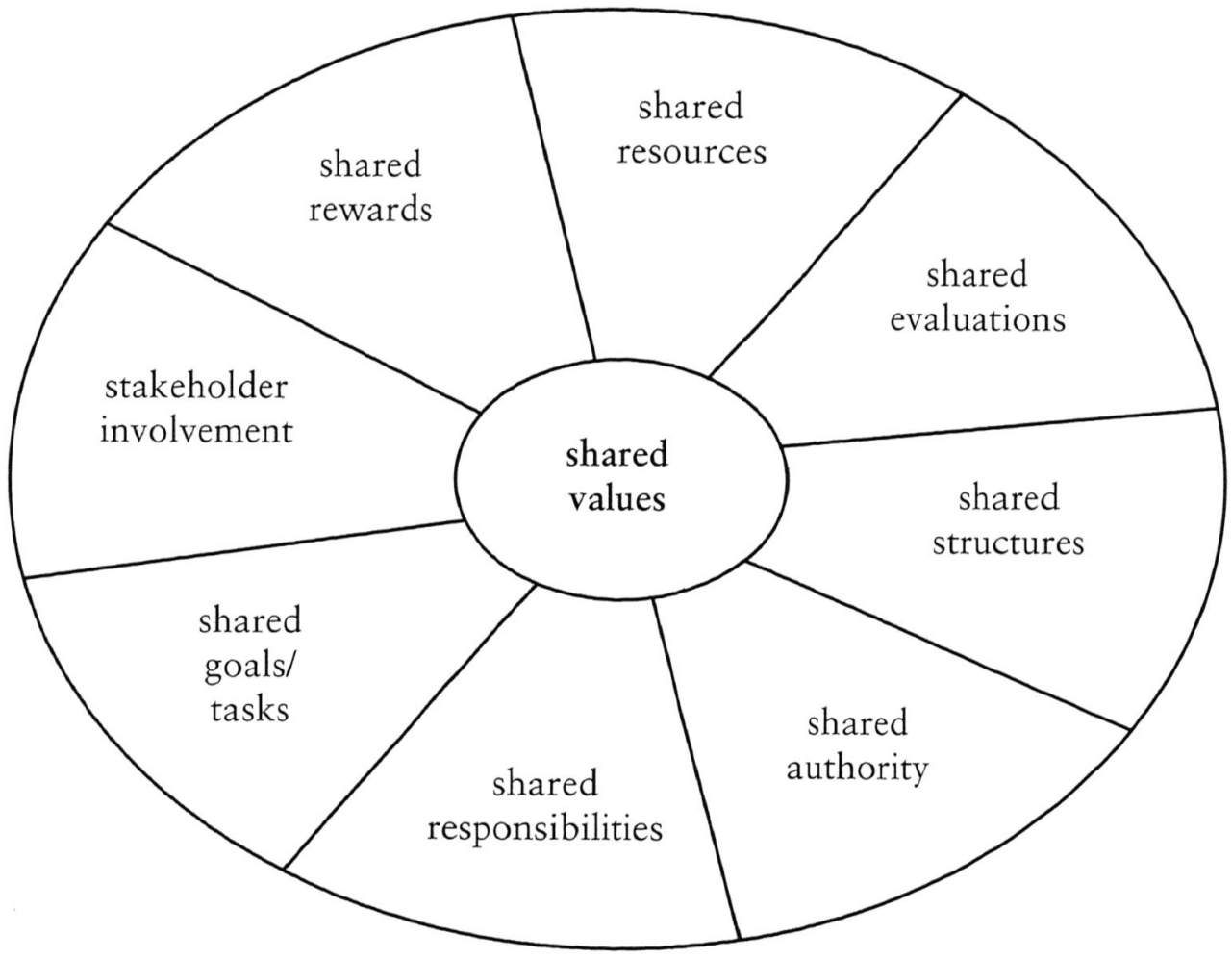


asserts that "consonance of values may be achieved by focusing on families and validating their own views of their needs and solutions, just as a focus on the customer has corrected many of the problems of quality faced by businesses" (p. 1339). Swan and Morgan (1993) declare that interagency collaboration requires a strong commitment to a system that is "family directed rather than program directed" (p. 24).

One of the distinguishing features of recent service-integration efforts has been its focus on the family, rather than the child, as the unit of service (Hassett \& Austin, 1997). In this respect, service-integration efforts have been reflecting a growing trend within separate service systems to reverse a historic emphasis on the child as the unit of service attention. In child welfare, for example, the family-preservation initiatives of the 1980s and 1990s sought to improve the permanency and well-being of abused and neglected children by bolstering and supporting the child's family. The Adoption and Child Welfare Act of 1980 required states to make "reasonable efforts" to prevent out-of-home placements and, if placement was necessary, to reunify children with their families. In special education, The Individuals with Disabilities Education Act of 1990 and its recent amendments have strongly recognized the need for parent and family involvement in children's educational plans (Petr, 1998).

Clearly, a family-centered philosophy is not without controversy and tension. Not all federal or state policies are family focused, and there can be legitimate professional concerns that necessitate professional abrogation of parent authority and decision making. Historically, professionals have been trained to consider the child as the unit of attention, and, bolstered by the philosophy of the Progressive Era, have not hesitated to replace parental judgement and authority with "expert" professional opinion (Petr \& Spano, 1990). But this child-centered, professional dominance has been one of the factors that has eroded the integrity of families and undermined the strength of the family as a social institution.

A common pitfall of emphasizing and promoting interagency collaboration is that the professional or the professional agency network is placed at the center of the helping system (Adams \& Nelson, 1997; Friesen \& Huff, 1996). When this occurs, several undesirable consequences can follow. The administrative and organizational processes between agencies can be highlighted at the expense of a focus on how these processes actually promote better outcomes for the children and families served. Traditional professional attitudes about the toxicity of families can also promote overuse of institutional and other out-of-home placements that perpetuate the poor outcomes of the traditional system (Petr \& Spano, 1990). Consumers tend to want service systems to provide more comprehensive choices, while professionals focus on streamlining services for the sake of efficiency (Hassett \& Austin, 1997).

\section{... without anchoring goals, objectives, and all other dimensions of the} collaborative process in a shared value base, interagency collaboration is futile.

Thus, the appropriate starting point for interagency collaboration and service integration is to establish and reify a community-wide value and belief system about families and about how to best support the child-rearing function of families. Although not without some controversy and risk, this focus is supported by the need to bolster the family as a social institution and the dangerous historical consequences of the dominance of professional values. This shared value base about families becomes the essential glue that can ensure the success of any service-integration effort, whether that effort involves formal interagency collaboration or the broader community of helping networks.

Family-centered attitudes involve four major elements (Allen \& Petr, 1998): (a) recognizing the centrality of families in the lives of individuals and choosing the family as the unit of attention; (b) maximizing families' choices and abilities for informed decision making; (c) applying a strengths perspective rather than a pathology focus; and (d) ensuring culturally sensitive services. It is evident that these four elements constitute a set of preferred values and attitudes about families and the relationship of service providers to families and their children.

The first element reverses a common historical trend across service systems that focused on the child as an individual, rather than on the child's family as 
the primary unit of attention. The second element combats the traditional professional tendency to make too many decisions for families, disregarding and sometimes undermining the parents' essential authority and responsibility. The third element provides an antidote to the parent blaming that has been extant in professional circles, recognizing instead that all families have strengths that can be developed and used in problem solving. The fourth element asserts that families may differ greatly in their views of helping professionals and service agencies, and thus need culturally competent services that value diversity and multiple perspectives. Together, these four elements represent a dramatic shift in traditional professional practices.

\section{Family-Centered Interagency Collaboration}

Based on systems theory and the literature of organizational management (Popper \& Lipshitz, 1998; Thietart \& Forgues, 1995), we know that the most efficient, successful systems incorporate key principles at all levels of the system. These functional, parallel relations are captured in the notions of "isomorphism" (the similarity of structures and phenomena across different levels) and "parallel processes" that have been identified as critical ingredients for effective services between levels of services (Eckstein \& Wallerstein, 1958; Gutierrez, GlenMaye, \& DeLois, 1995; Hose, 1998). For example, the literature about total quality management (TQM) within the human-service area (Edwards, Cooke, \& Reid, 1996; Ginsberg \& Keys, 1995; Gummer \& McCallion, 1995; Gunther \& Hawkins, 1996; Keys, 1995; Martin, 1993; Moore \& Kelly, 1996; Rago, 1996) proposes that consumer empowerment, employee empowerment, and organizational empowerment are "functionally related, if not equally necessary as components of a single system" (Rago, 1996, p. 228). Thus, if family-centered principles are the core values in a system of care, then we would expect to find the four components of a family-centered attitude at all of the levels of the service system, from the "lowest" level of direct service, vertically up through the policies and procedures of the organization, and horizontally out into the relationships between service organizations and the larger community.

Currently, indicators and measures for familycentered attitudes and behaviors exist at the individual level between consumer and professional. For ex- ample, the Family-Centered Behavior Scale (FCBS) (Allen, Petr, \& Brown, 1995) evaluates the responsiveness of service programs to families by measuring the degree to which individual professional behavior is family centered from the perspective of parents (Petr \& Allen, 1997). Also, there are measures and indicators for program and intraorganizational aspects of being family centered (Murphy \& Lee, 1991; Friesen \& Koroloff, 1990). Currently missing are indicators for the degree of family-centered attitudes at the interagency level. At this level, being family centered is enacted in the formal and informal structures and policies that exist between agencies.

Indicators for the degree of interagency familycentered attitudes that translate the four principles (family as unit of attention, maximizing families' ability to make decisions, applying a strengths perspective, and cultural sensitivity) into the horizontal processes of collaboration between agencies need to be developed. If family-centered attitudes and behaviors are to be the guiding value system for a community system of care, then they should be clearly evident at all levels of the service system, from the interactions between families and direct providers, to the internal processes within organizations, and to the actions and behaviors of interagency collaboratives (see Figure 3).

To develop ideas about what might constitute the best, or ideal, family-centered interagency practices, the authors sought the expert wisdom of a number of key informants from education, early intervention, mental health, health care, developmental disability, and child welfare. This small, convenience sample of 14 participants included consumers, frontline workers, supervisors, and administrators from different areas throughout the United States and Canada, all noted for their exemplary efforts on behalf of families and their commitment to a family-centered philosophy of service. This informal survey and conversation with key informants was conducted to generate ideas and discuss experiences, with no attempt to formally codify the results. The following suggestions are based on the ideas of participants and the authors.

Communities that attempt to improve interagency collaboration and service integration usually form some type of interagency council that serves as a steering body, which catalyzes and monitors the collaborative process. In a system guided by a shared emphasis on family-centered values, this interagency body would promote family-centered approaches both within member agencies and between them. 
Figure 3. Vertical and Horizontal Processes of Family-Centered Collaboration

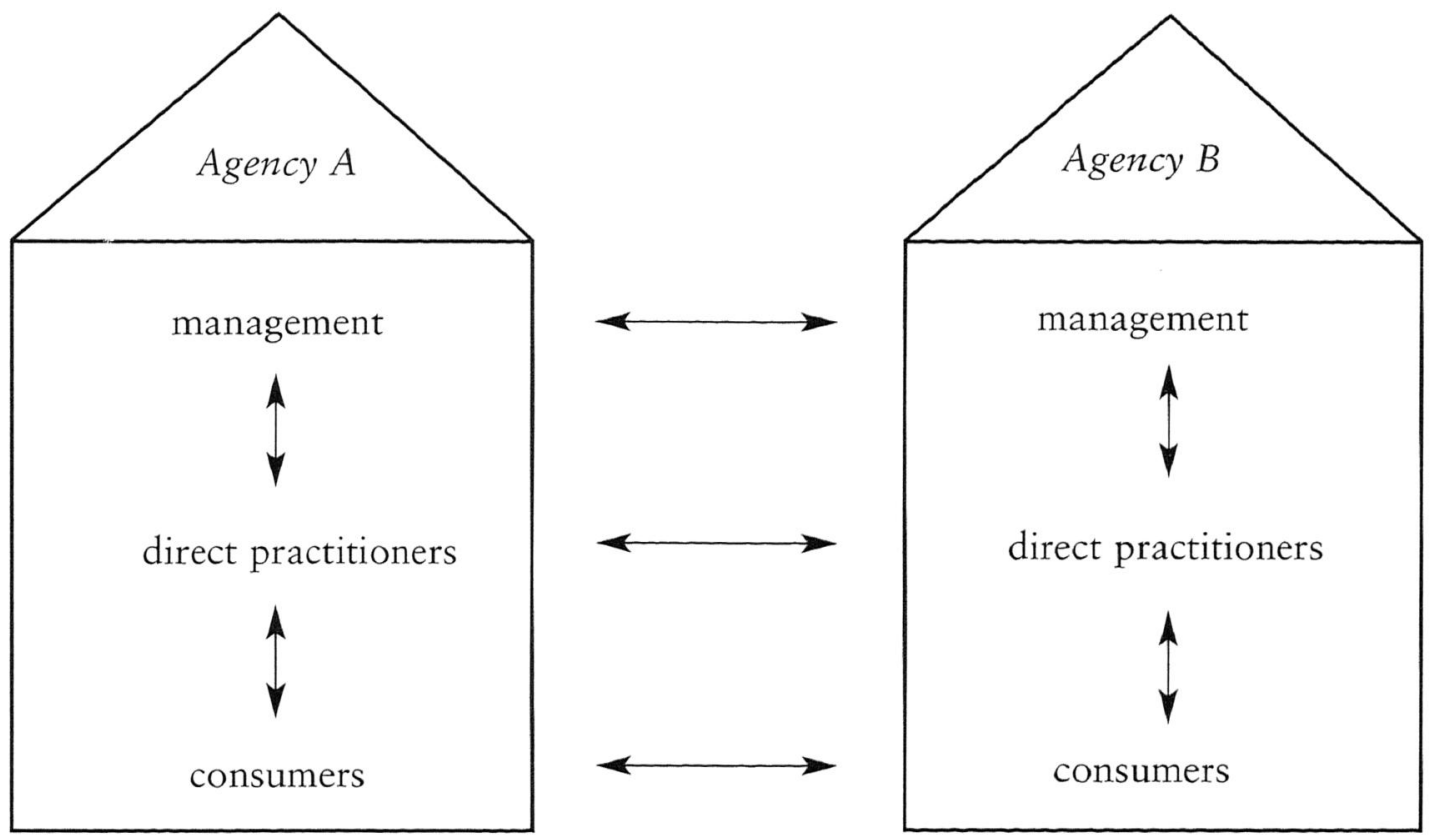

$\longleftrightarrow=$ Family-centered attitudes and behaviors

Indicators for how to make family-centered values operational within agencies are listed in Table 1 . Because the indicators listed under the first three subcategories (mission statement, family/consumer advisory committee, policies and procedures) have been discussed elsewhere in the literature (see, for example, Friesen \& Koroloff, 1990; Lawson \& Briar-Lawson, 1997), they will not be extensively discussed in this article. Still, as participants in our informal survey pointed out, these ideas continue to exist in theory more than in reality as many agencies struggle to fully implement family-centered policies and practices.

What has rarely been emphasized in the literature is that the same respectfulness and responsiveness by organizations to families must, in turn, be granted to frontline workers. As Adams and Nelson (1997) point out,

There is in human services a parallel process whereby the powerlessness often experienced by families in the face of a bureaucratic and threatening human services system is reproduced in the disempowered line worker whose capacity to use professional judgment or even common sense is tightly circumscribed by mandated procedures, rules and regulations. (p. 74)

Recognizing that staff members are family members as well, agency policies need to allow for flexible work hours, emergency leave, on-site child care, and leave to care for sick family members. Involving frontline staff teams in agency planning and decision making reflects a management style that models the essence of collaboration. Feedback needs to be elicited frequently from all staff about their job satisfaction and management decisions, processes, and styles. Like families, staff must be informed in timely and complete ways about plans and meetings and about organizational agendas, and their suggestions must be taken seriously.

If a collaborative management style is to be modeled, policies must allocate staff the time and resources to process ideas, work on suggestions, and participate in meetings. Parallel to the interaction with families, staff must be encouraged to bring the diversity of their perspectives and talents to the workplace. The ethnic composition of staff on all levels (frontline, middle 
Table 1. Checklist of Indicators for Family-Centered Practice Within Agencies

1. Mission statement

$\square$ written with participation of families

$\square$ written with participation of management and direct-practice staff

states importance of families, a commitment to support families and enhance family well-being

commitment to define "family" broadly and nontraditionally

$\square$ commitment to outreach poor, minority, and other vulnerable populations

2. Family/ consumer advisory committee

$\square$ adequate representation of consumer families on board of directors and other decision-making bodies

family-advisory committee is established in agencies and meets regularly; or at least $50 \%$ of any general advisory committee are consumers

family representatives on advisory committee feel valued and heard

$\square$ ethnic compositions of board of directors and advisory committees mirror that of client population

$\square$ policies regarding programming and hiring reviewed by advisory committee

3. Policies and procedures

$\square$ easy access to information (client records, agency, alternative programs, referrals, grievances, client rights, bilingual material, etc.)

$\square$ family resource room run by and for families

$\square$ child care available and affordable

$\square$ support for transportation provided

$\square$ reimbursement for participation on committees

$\square$ flexible office hours

$\square$ flexible locations (satellite offices, home visits)

$\square$ staff performance evaluations include consumer satisfaction

$\square$ regular (at least yearly) systematic consumer satisfaction surveys, with evidence that results are used to make changes

$\square$ ethnic composition of staff at all levels mirrors that of client population

$\square$ regular staff training in family-centered principles and cultural diversity

4. Treatment of staff

$\square$ flexible work hours

$\square$ emergency family leave

$\square$ on-site child care

$\square$ frontline staff directly involved in agency planning and decision making

$\square$ regular surveys of job satisfaction and satisfaction with management

$\square$ staff time allocated for supervision, discussion of issues

$\square$ staff time allocated for continuing education

management, and upper management) will reflect the diversity in the community served. Ongoing training and staff meetings attend to issues of diversity and offer opportunities to consult.

The aforementioned suggestions about familycentered collaboration within an agency find their logical extensions for collaborative processes between agencies (see Table 2). Here, an interagency council becomes the steering body that catalyzes and monitors the collaborative process. The council would first develop a joint mission statement in which familycentered values are clearly expressed and agreed upon. Such a mission statement would include a commitment of participating agencies to the preservation and support of the family as the primary unit of social or- ganization. The dedication to this mission is then made operational through joint commitments and efforts; for example, to reduce the number of out-ofhome placements, minimize the frequency and effects of separation and divorce, and/or lift families out of poverty.

Membership in interagency councils has often been restricted to managers or other staff from participating agencies. In contrast, a family-centered interagency council includes a meaningful number of consumer representatives, citizens at large, and agency management and frontline staff.

Effective functioning of interagency councils requires frequent reviews of progress and barriers. Interagency councils must remain in close contact with the 
Table 2. Checklist of Indicators for Family-Centered Practice Between Organizations

1. Mission statement

$\square$ joint endorsement of family-centered principles and the importance of the family as a social institution

$\square$ common outcome objectives that support families

2. Membership

$\square$ includes families, citizens, and frontline workers

3. Accountability to family-centered outcomes

$\square$ collection and use of aggregated data

$\square$ case level reviews

$\square$ publicize success stories

4. Accountability to family-centered values

$\square$ regular checklist assessment ("accreditation") of agency practices

$\square$ convene diverse focus groups

5. Maximize family decision making

$\square$ grants to family organizations

$\square$ formation of family-centered citizen review boards (FCCRBs)

6. Promote family-centered values in the larger community

link informal support systems

$\square$ recognize and honor exemplary agencies/programs/individuals

very families they are ultimately serving. Councils need to review individual cases on a regular basis to directly learn from families, frontline staff, and other members of the community what has worked and what barriers they have encountered. Celebrating successes is an essential part of strengths-oriented interagency collaboration. Success stories of individual families can be publicly recognized through award and reward systems. An interagency council could encourage and support publications and invite media reports that represent families' accounts of how they overcame obstacles.

In a family-centered system, a principal function of an interagency council would be to ensure the family-centered attitude of the entire service system and the surrounding community. The council would thus hold its members accountable to the mission statement and for making family-centered values operational throughout the organization. This accountability function could be implemented in at least two ways.

First, interagency councils could survey, and even accredit, agencies in the community. Using a checklist of preferred indicators of family-centered practices (see Table 2), this council could regularly and routinely assess agency performance, compute an overall score, and identify areas of strength and needed improvement. In a fashion very similar to an accredita- tion process, the checklist could be used to develop standards and assign a rating score that clearly indicates level of family-centered performance on each of the standards. This rating could be used to inform potential consumers as well as funding sources.

Second, borrowing from a suggestion by Urwin and Haynes (1998), councils could adopt a reflexive model of interagency collaboration using focus groups to share experiences and ideas, build relationships, and redefine problems, solutions, and priorities. While Urwin and Haynes's model involves only staff and supervisors, a family-centered collaboration model would emphasize focus groups that are either exclusively composed of consumers or in which at least $50 \%$ of participants are consumers. In addition to this modification of membership, the purpose of these groups would change to include monitoring of familycentered core values.

To maximize the decision-making power of families, the interagency council could fund family groups to direct some component of the interagency initiative or perhaps even to direct the council itself. These family-led interagency councils could decide on benchmarks appropriate for the collaborative process (O'Looney, 1997), hire council staff, and allocate pooled money. Families would thus become employers of staff and directors of interagency collaboration. 
Alternatively, the council could form a familycentered citizen review board (FCCRB), consisting of community representatives, which could become the overseeing body to the interagency collaborative. It could hold the system accountable for the degree to which it is family-centered and promotes familycentered principles. This FCCRB could, for example, conduct the regular "accreditation" visits to agencies, as described above.

Moving the focus of interagency collaboration efforts beyond the formal helping system, an interagency council needs to recognize the array of informal supports used by families (Friesen \& Koroloff, 1990). The role of an interagency council is to identify and link these support systems and to promote familycentered values and attitudes in the larger community. The council could sponsor in-service training, workshops, and other educational events that capitalize on the strengths and resources that already exist in the local community. Human-service agencies could learn from successful local businesses about management models and strategies that "humanize the workplace" (Austin, 1997). Churches or other community associations could share their expertise about cultural and religious assets and customs important to families.

To promote "best practices," a council could identify local businesses, churches, or clubs that already stand out in the way they include and serve families and employees. An interagency council could ask for yearly nominations of community organizations and award public recognition to successful examples of family-centered approaches.

\section{Conclusion}

Efforts to improve interagency collaboration and service integration have proliferated in recent years. The available literature has emphasized that the success of interagency collaboration efforts depends, in large part, on the extent to which participants share a common vision and values. Yet, there has been scant attention given to the definition and explication of this core dimension in the literature.

This article has posited a rationale and framework for establishing a family-centered value system as the essence of the shared value system. The success of interagency collaboration in improving outcomes for children and their families may well depend on those collaborative efforts being anchored to a shared vision about the absolute, paramount importance of the family as a social institution. Community agencies can succeed by working in a community context that supports the integrity and viability of families. Family support can and should be operationalized into meaningful, measurable behaviors at the professional, organizational, and community levels.

In this framework, interagency councils function to define these family-centered behaviors and to hold member agencies accountable to them. Within organizations, family-centered behavior goes beyond empowering families to empowering staff as well, so that all levels of the agency and community are synchronized in their commitment to the shared vision and values.

\section{References}

Abramson, J., \& Rosenthal, B. (1995). Interdisciplinary and interorganizational collaboration. Encyclopedia of Social Work (19th ed., Vol. 2, pp. 1479-1489). Washington DC: NASW Press.

Adams, P., \& Nelson, K. (1997). Reclaiming community: An integrative approach to human services. Administration in Social Work, 21(3/4), 67-81.

Allen, R., Petr, C., \& Brown, B. (1995). Family-centered bebavior scale and manual. Lawrence, KS: The Beach Center on Families and Disabilities, University of Kansas.

Allen, R. I., \& Petr, C. G. (1998). Rethinking family-centered practice. American Journal of Orthopsychiatry, 68(1), 4-16.

Austin, M. (1997). Service integration: Introduction. Administration in Social Work, 21(3/4), 1-7.

Bailey, D., \& Koney, K. M. (1996). Interorganizational communitybased collaboratives: A strategic response to shape the social agenda. Social Work, 41(6), 602-611.

Bruner, C. (1991). Thinking collaboratively: Ten questions and answers to help policy makers improve children's services. Oak Brook, IL: North Central Regional Educational Laboratory.

Eckstein, R., \& Wallerstein, R. S. (1958). The teaching and learning of psychotherapy. New York: Basic Books.

Edwards, R. L., Cooke, P. W., \& Reid, P. N. (1996). Social work management in an era of diminishing federal responsibility. Social Work, 41(5), 468-479.

Friesen, B. J., \& Huff, B. (1996). Family perspectives on systems of care. In B. A. Stroul (Ed.) Children's mental health, creating systems of care in a changing society (pp. 41-67). Baltimore: Brookes.

Friesen, B. J., \& Koroloff, N. M. (1990). Family-centered services: Implications for mental health administration and research. Journal of Mental Health Administration, 17(1), 13-25.

Ginsberg, L., \& Keys, P. R. (Eds.) (1995). New management in buman services (2nd ed.). Washington, DC: NASW Press.

Gummer, B., \& McCallion, P. (Eds.) (1995). Total quality management in the social services. Albany, NY: Rockefeller College of Public Affairs and Policy.

Gunther, J., \& Hawkins, F. (1996). Total quality management in buman service organizations. New York: Springer.

Gutierriez, L., GlenMaye, L. , \& DeLois, K. (1995). The organizational context of empowerment practice: Implications for 
social work administration. Social Work, 40(2), 249-258.

Harbert, A. S., Finnegan, D., \& Tyler, N. (1997). Collaboration: A study of a children's initiative. Administration in Social Work, 21(3/4), 83-107.

Hassett, S., \& Austin, M. (1997). Service integration: Something old and something new. Administration in Social Work, 21(3/4), 9-29.

Hose, C. P. (1998). Supervision and family-centered practice: The parallel process. Unpublished manuscript, Division of Child and Family Services, Carson City, NV.

Jesien, G. S. (1996). Interagency collaboration: What, why, and with whom? In P. Rosin, A. D. Whitehead, L. I. Tuchman, G. S. Jesien, A. L. Begun, \& L. Irwin (Eds.), Partnerships in family-centered care: A guide to collaborative early intervention (pp. 187-201). Baltimore: Brookes.

Kagan, S. L. (1991). United we stand: Collaboration for child care and early education services. New York: Teachers College Press.

Kagan, S. L. (1993). Integrating services for children and families. New Haven, CT: Yale University Press.

Kagan, S. L., \& Pritchard, E. (1996). Linking services for children and families: Past legacy, future possibilities. In E. Zigler, S. L. Kagan, \& N. W. Hall (Eds.), Children, families and government (pp. 378-393). Cambridge, MA: Cambridge University Press.

Keys, P. R. (1995). Quality management. In R. L. Edwards (Ed.-inChief), Encyclopedia of social work (19th ed., Vol. 3, pp. 2019-2025). Washington, DC: NASW Press.

Konrad, E. L. (1996). A multidimensional framework for conceptualizing human services integration initiatives. New Directions for Evaluations, 69, 5-19.

Lawson, H., \& Briar-Lawson, K. (1997). Connecting the dots: Progress toward the integration of school reform, schoollinked services, parent involvement and community schools (Monograph). Oxford, OH: Danforth Foundation and the Institute for Educational Renewal at Miami University.

Martin, L. L. (1993). Total quality management in buman service organizations. Newbury Park, CA: Sage.

Mattessich, P. W., \& Monsey, B. R. (1992). Collaboration: What makes it work? St. Paul, MN: Amherst Wilder Foundation.

Melaville, A., \& Blank, M. (1991). What it takes: Structuring interagency partnerships to connect children and families with comprehensive services. Washington, DC: Education and Human Services Consortium.

Moore, S., \& Kelly, M. (1996). Quality now: Moving human services organizations toward a consumer orientation to service quality. Social Work, 41(1), 33-40.

Morgan, G. (1997). Collaborative models of service integration. Child Welfare, 74(6), 1329-1342.

Murphy, D. L., \& Lee, I. M., (1991). Family-centered program rating scale: User's manual. Lawrence, KS. University of Kansas Beach Center on Families and Disability.

National Commission on Children. (1991). Beyond rhetoric: A new agenda for children and families: Final report of the National Commission on Children. Washington, DC: U.S. Government
Printing Office.

O’Looney, J. (1994). Modeling collaboration and social services integration: A single state's experience with developmental and non-developmental models. Administration in Social Work, 18(1), 61-86.

O’Looney, J. (1997). Marking progress toward service integration: Learning to use evaluation to overcome barriers. Administration in Social Work, 21(3/4), 31-65.

Petr, C. G. (1998). Social work with children and their families, pragmatic foundations. New York: Oxford University Press.

Petr, C. G., \& Allen, R. I. (1997). Family-centered professional behavior: Frequency and importance to parents. Journal of Emotional and Behavioral Disorders, 5(4), 196-201.

Petr, C. G., \& Spano, R. N. (1990). Evolution of social services for children with emotional disorders. Social Work, 35, 228-234.

Popper, M., \& Lipshitz, R. (1998). Organizational learning mechanisms: A structural and cultural approach to organizational learning. Journal of Applied Behavioral Science, 34(2), 161179.

Rago, W. V. (1996). Struggles in transformation: A study in TQM, leadership, and organizational culture in a government agency. Public Administration Review, 56(3), 227-234.

Swan, W. Q., \& Morgan, J. L. (1993). Collaborating for comprehensive services for young children and their families. Baltimore, MD: Brookes.

Thietart, R. A., \& Forgues, B. (1995). Chaos theory and organization. Organization Science, 6(1), 19-31.

Urwin, C., \& Haynes, D. T. (1998). A reflexive model for collaboration: Empowering partnerships through focus groups. Administration in Social Work, 22(2), 23-39.

Uta M. Walter is a doctoral student and research assistant and
Christopher G. Petr is associate professor, School of Social Welfare,
University of Kansas, Twente Hall, Lawrence, KS 66045-2510.

Authors' note: This article was researched and written with the support of the National Institute on Disability and Rehabilitation Research, U.S. Department of Education, grant H133B30070 to the Beach Center on Families and Disability, University of Kansas, and Contract No. 99-11 between the University of Kansas and the Kansas Department of Social and Rehabilitation Services.

The authors wish to acknowledge the contributions by Jane Adams, Theresa Anderson, Della Beattie, Gwen Beegle, Isobel Boyle, Sonia Buska-Owczar, Kim Hirte, Cynthia Hose, Barbara Huff, Cathy Mogharreban, Debbie Nielsen, Carol Potter, Saul Singer, and Mary Telesford to the concepts and ideas presented in this article.

Original manuscript received: July 27, 1999

Revised: January 31, 2000

Accepted: February 11, 2000 